\title{
Araştırma Makalesi/Research Article (Original Paper) \\ Evaluation of The Effect of Salinity on Some Physiological and Phenological Traits in Durum Wheat Cultivars
}

\author{
Sonia KAHRIZI*1, Mohammad SEDGHI ${ }^{2}$, Omid SOFALIAN ${ }^{2}$ \\ ${ }^{1}$ : MSc in Seed Science and Technology, University of Mohaghegh, Ardabili \\ 2 : Department of Agronomy and Plant Breeding, Faculty of Agricultural Sciences, University of \\ Mohaghegh Ardabili, Ardabil 179 \\ Corresponding author: mosedghi2003@yahoo.com
}

\begin{abstract}
To evaluate the effect of salinity on some physiological and phenological traits in durum wheat, a factorial experiment was conducted based on randomized complete block design with three replicates. Treatment was salinity with three levels including control, 60 and $120 \mathrm{mM}$ on ten durum wheat cultivars (Boomer, PGS, 71135, 61130, 605, C1351, KND1000, KDM, Haurani and G1252). Time of stem elongation, time to heading and maturity, chlorophyll content and chlorophyll fluorescence of flag leaf were measured. Results showed that the interaction between salinity and cultivars was significant only for heading time. With increasing salinity in both 61130 and PGS cultivars, heading time increased. Boomer had the lowest maturity time, while PGS had the greatest time to maturity. About the time of stem elongation, 605 and 61130 respectively had the minimum and maximum time of stem elongation. The interaction of salinity and cultivars was not significant for chlorophyll content in the flag leaf, but chlorophyll fluorescence $\left(\mathrm{F}_{\mathrm{V}} / \mathrm{F}_{\mathrm{M}}\right)$ of flag leaf was significant. C1352 and 71135 respectively had the highest and lowest chlorophyll content in flag leaf.
\end{abstract}

Key words: Salinity, Physiological traits, Durum wheat, Chlorophyll fluorescence

\section{Makarnalık Buğday Çeşitlerinin Bazı Fizyolojik ve Fenolojik Özellikleri Üzerine Tuzluluk Etkisinin Değerlendirilmesi}

Özet: Makarnalık buğday çeşitlerine bazı fizyolojik ve fenolojik özellikleri üzerinde tuzluk etkisini değerlendirmek için, deneme Tesadüf Bloklar Deneme Desenine göre üç tekrarlamalı olarak kurulmuştur. Denemede kontrol dahil 2 tuz seviyesi $(60,120 \mathrm{mM})$ ve 10 makarnalı buğday çeşidi (Boomer, PGS, 71135, 61130, 605, C1351, KND1000, KDM, Haurani ve G1252) kullanılmıștır. Kök uzama süresi, başaklanma ve olgunlaşma zamanı, bayrak yaprağının klorofil içeriği ve floresanı gibi özellikler ölçülmüş̧ür. Araştırma sonuçlarına gore; tuzluluk ve çeşitlerin etkileşiminin sadece başaklanma süresi bakımından önemli olduğu bulunmuştur. Hem 61130 hem de PGS çeşitlerinde başaklanma süresi tuzluluğun artışına bağlı olarak artış göstermiştir. PSG çeşidi daha uzun bir olgununlama süresine sahip iken, Boomer çeşidi en düşük olgunlaşma süresine sahip olmuştur. Kök uzama süresi incelenecek olursa, 605 buğday çeşiti en düşük ve 61130 buğday çeşiti ise en yüksek kök uzama süresine sahip olmuşlardır. Tuzluluk ve çeşitlerin etkileşimi bayrak yaprağ klorofil içeriği bakımından önemsiz bulunmuş ancak, bayrak yaprağı klorofil floresan bakımından önemli (FV / FM) olarak saptanmıştır. C1352 ve 71135 çeşitlerinde bayrak yaprağı klorofil içeriği sırasıyla en yüksek ve en düşük olarak saptanmıştır.

Anahtar kelimeler: Tuzluluk, Fizyolojik özellikler, Makarnalık buğday, Klorofil floresan

\section{Introduction}

Phenological traits are the most important traits of plants adapted to different environmental conditions. These traits can minimize the reduction of yield by changing duration of vegetative and reproductive growth of plants under stress (Golabadi et al. 2008). The period of each development stage depends essentially on genotype, temperature, day length and sowing date. Various environmental stresses particularly heat, but also water and salinity may shorten the wheat growth phases (Acevedo et al. 2002). The reduction in growth is a consequence of several physiological responses, including water status, modification of ion balance, carbon allocation and utilization and toxic ions (Termatt and Munns, 1986; 
Munns, 1993). The response of phenological aspects to salinity changes with developmental stages of plant (Neumann, 1995). For example, many crops show a reduced tolerance to salinity during seed germination, but greater tolerance during later growth stages and vice versa in other crops. Results of salt tolerance for some crops have shown that wheat, sorghum and cowpea (Mass and Poss, 1989) were most sensitive during the vegetative and early reproductive stages, less sensitive during flowering, and least sensitive during the grain filling stage.

During early seedling growth, the major effect of salt stress on the timing of shoot primordial initiation is to reduce the duration of the spikelet initiation phase, whereas the period from sowing to flag leaf initiation is unaffected by salinity (Grieve and et al. 1994). A review (McMaster et al. 1992a) of published estimates of phyllochron intervals reveals that booting occurs 2 phyllochrons after flag leaf appearance, 3 phyllochrons after jointing, and 0.5 phyllochrons prior to heading. Soil salinity accelerates apex development and increases the phyllochron leading to reducing the number of leaves in the main shoot (Maas and Grieve 1986). It also decreases the number of spikelets in the main spike (Frank et al. 1987) and anticipates crop maturity. All phenological phases are accelerated under salinity stress in wheat (Grieve et al. 1994). Spike development is accelerated, decreasing the time to terminal spikelet and the crop cycle. Kafi (2001) showed that the rate of spikelet initiation increases in mild salt concentration as compared with control, but at the highest level of salinity this rate was reduced. Although at high salinity, both the duration and rate of spikelet initiation were reduced. Reduction in the rate of spikelet initiation was relatively more than the duration. Iqbal et al (2006) and Ashraf et al (2005) reported that chlorophyll content was decreased under saline conditions. Moussa Helal (2006) showed that salt stress significantly decreased both chlorophyll $\mathrm{a}$ and $\mathrm{b}$ content. Ashrafuzzaman et al (2000) showed with increasing salinity Chlorophyll a, b, total Chlorophyll $(\mathrm{a}+\mathrm{b})$ and Chlorophyll $\mathrm{a} / \mathrm{b}$ were reduced. Salinity can affect chlorophyll content through inhibition of chlorophyll synthesis or an acceleration of its degradation (Zhao et al. 2007). Other researchers suggested that more accumulation of sodium $\left(\mathrm{Na}^{+}\right)$ions in shoots of salt sensitive genotypes (compared to the salt tolerant ones), is one of the most important factors affecting chlorophyll losses (Dingkuhn et al. 1992). Chlorophyll (chl) fluorescence could be used for screening of salt tolerance cultivars and modified by salinity stress (Baker and Rosenqvist 2004). Chl fluorescence provides non-invasive and rapid method for estimates of photosynthetic performance of plants (Kao et al. 2003; Baker and Rosenqvist 2004).

Ratio of $\mathrm{F}_{\mathrm{V}} / \mathrm{F}_{\mathrm{M}}$ estimates performance of photosystem $\Pi$ and $\mathrm{Fv}$ indicates the difference between maximum fluorescence and optimum fluorescence. The ratio for normal function of leaves is between $0.75-0.85$ and its reduction shows the Inhibitory damage (Dell et al. 1999). Zaire et al (2003) noted that the $F_{V} / F_{M}$ ratio decreased significantly in salt sensitive line and remained unchanged intolerant one in wheat. Misra et al (2001) reported that quantum performance $\left(\mathrm{F}_{\mathrm{V}} / \mathrm{F}_{\mathrm{M}}\right)$ is as an early indicator of salinity. Photosystem $\Pi$, is very sensitive to inhibitory environmental factors and the salt stress causes damage to the reaction center of photosystem $\Pi$. Analysis of chlorophyll fluorescence induction curves showed that inhibition of the activity of reaction center in photosystem $\Pi$ is the main effects of salt stress in wheat cultivars (Zhao et al. 2001).

The objectives of this study were to determine the effects of salinity on the physiological and phenological traits in durum wheat cultivars.

\section{Materials and Methods}

In order to evaluate the salinity impact on some physiological and phenological characters in ten durum wheat cultivars, a factorial experiment was conducted based on completely randomized design with three replications in a greenhouse with $25 / 15^{\circ} \mathrm{C}$ day/night temperature and $14 / 10$ hours day/night photoperiod at the University of Mohaghegh Ardabili, Ardabil, Iran. Salt concentrations were 0, 60 and $120 \mathrm{mM}$ that applied in two stages (before shooting and before booting) and ten durum wheat cultivars including Boomer, PGS, 71135, 61130, 605, C1351, KND, KDM, Haurani and G1252. These cultivars were obtained from the Research Institute of Maragheh, Iran. In this study, traits like the time of stem elongation, heading and maturity time, chlorophyll content and chlorophyll fluorescence of flag leaf were measured. Leaf color was measured after salt stress imposed by using the Chlorophyll meter (SPAD-502 Minolta Co., Japan) as estimation of leaf chlorophyll content. Four records from the flag leaf were taken and mean of them considered as leaf chlorophyll estimation. In flag leaf chlorophyll fluorescence was measured using the Chlorophyll Fluorometer (OS-30P US manufacturing companies Opti Science). As 
such, in leaf samples, some clamps installed on the leaves to create the desired conditions of darkness and then, after 30 min readings were done. In this case, parameters $F_{O}, F_{m}$ and $F_{V} / F_{M}$ were recorded. $F_{O}$ is the optimal fluorescence, $\mathrm{F}_{\mathrm{m}}$ is maximum fluorescence, $\mathrm{F}_{\mathrm{V}}$ is difference between optimum and maximum fluorescence and $\mathrm{F}_{\mathrm{V}} / \mathrm{F}_{\mathrm{M}}$ is the quantum yield. Analysis of variance was performed by SAS 9.1 software and means were ordered by the Slice command of the software.

\section{Results and Discussion}

Results showed that the interaction between salinity and cultivar was significant only for heading time at $1 \%$ probability level (Table 1). There were significant differences between cultivars at 1\% probability level for stem elongation time, heading and maturity. Boomer showed minimum time to maturity and PGS showed the greatest time of maturity. About the time of stem elongation, 605 and 61130 , respectively, had the minimum and maximum time of stem elongation (Fig 1).

Salt stress decreased the time from sowing to maturity in wheat by reducing the duration of specific growth stages, i.e., spikelet initiation, booting, heading, and anthesis (Grieve et al. 1994; Acevedo et al, 2002). Increasing salinity increased heading time in cultivars 61130 and PGS (Fig 2). Kafi (2001) showed that the rate of spikelet initiation increased in mild salt concentration as compared with control, but at the highest level of salinity this rate was reduced. This result does not agree with Oosterhuis and Cartwright (1983) who reported that there was no correlation between the length of the spike initial and the number of spikelet primordia formed in water stressed wheat plants. Although at high salinity, both the duration and rate of spikelet initiation were reduced, reduction in the rate of spikelet initiation was relatively more than the duration.

Figure 1. Comparison of means for time of stem elongation and maturity in durum wheat cultivars $(\mathrm{P}<1 \%)$
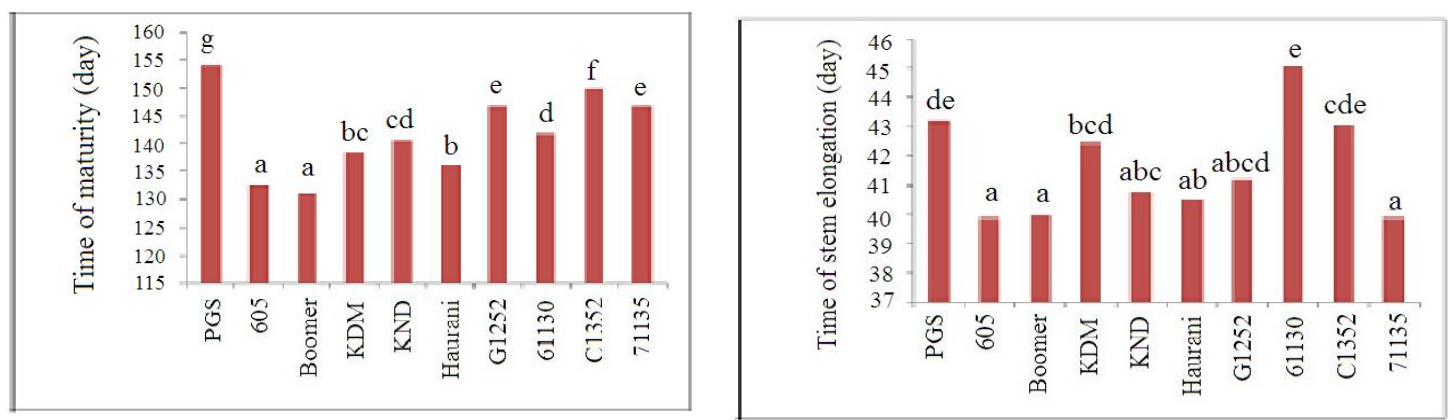

Interaction of salinity and cultivar was not significant for chlorophyll content (leaf greenness) in flag leaf (Table 1). There were significant differences between cultivars at 5\% probability level for chlorophyll content. Also, there were significant differences between different levels of salinity at 5\% probability level so that the control had the maximum chlorophyll content and salinity level of $120 \mathrm{mM}$ had the lowest chlorophyll content in flag leaf (Fig 3). Among cultivars, C1352, and 71135, respectively had the highest and lowest chlorophyll content in the flag leaf (Fig 3). Pessarkli (1999) stated that the duration of leaf photosynthesis and chlorophyll maintenance under stress are the physiological indicators of stress resistance. Reddy and Vora (1986) reported that salinity reduces the amount of chlorophyll and carotenoids and the reduced chlorophyll content under saline conditions, was associated with higher activity of enzyme chlorophyllase. Salinity increases concentration of growth regulators such as abscisic acid and ethylene which stimulate chlorophyllase, thus, chlorophyll degradation is affected by this enzyme (Drazkiewics 1994).

Interaction between salinity and cultivars for chlorophyll fluorescence traits $\left(F_{V} / F_{M}\right)$ of flag leaf was significant (Table 1). Cultivars had significant difference with each other's in chlorophyll fluorescence. In mean compares on Table 2, KDM and Haurani respectively, showed the highest and the lowest chlorophyll fluorescence at control salinity level. At $60 \mathrm{mM}$, Boomer and C1352, and at $120 \mathrm{mM}$, Boomer and G1252, respectively, had the highest and the lowest chlorophyll fluorescence (Table 2). Ratio $\mathrm{F}_{\mathrm{V}} / \mathrm{F}_{\mathrm{M}}$ estimates performance of photosystem $\Pi$ and $\mathrm{Fv}$ indicates the difference between maximum 
fluorescence and optimum fluorescence. The ratio for normal function of leaves is between $0.75-0.85$ and its reduction shows the inhibitory damage (Dell et al. 1999).

Table 1. Analysis of Variance for the Effect of Salinity on physiological and phenological characters in durum wheat cultivars

\begin{tabular}{|c|c|c|c|c|c|c|}
\hline \multirow[b]{2}{*}{ Source of variation } & \multicolumn{6}{|c|}{$\begin{array}{c}\text { Means of } \\
\text { square }\end{array}$} \\
\hline & d.f & $\begin{array}{c}\text { Chlorop } \\
\text { hyll } \\
\text { content }\end{array}$ & $\begin{array}{l}\text { Chlorophyll } \\
\text { Fluorescenc } \\
\text { e of flag leaf }\end{array}$ & $\begin{array}{r}\text { Time of } \\
\text { Stem } \\
\text { elongation }\end{array}$ & $\begin{array}{l}\text { Time of } \\
\text { heading }\end{array}$ & $\begin{array}{c}\text { Time of } \\
\text { maturity }\end{array}$ \\
\hline Replication & 2 & $51.490 \mathrm{~ns}$ & $0.0001 \mathrm{~ns}$ & $95.511 * *$ & $27.733 \mathrm{~ns}$ & $1.527 \mathrm{~ns}$ \\
\hline Salinity & 2 & $\begin{array}{c}165.58 \\
8^{*}\end{array}$ & $0.001 \mathrm{~ns}$ & $0.044 \mathrm{~ns}$ & $54.233^{*}$ & $1.005 \mathrm{~ns}$ \\
\hline Cultivar & 9 & $71.831^{*}$ & $0.004^{* *}$ & $28.277 * *$ & $920.248 * *$ & $2.844^{* *}$ \\
\hline Salinity $\times$ Cultivar & 18 & $\begin{array}{l}22.486 \\
\text { ns }\end{array}$ & $0.001 \mathrm{~ns}$ & $2.662 \mathrm{~ns}$ & $49.419 * *$ & 0.966 \\
\hline Error & 58 & 33.694 & 0.0003 & 3.787 & 17.124 & 0.551 \\
\hline c.v\% & & 15.24 & 2.61 & 4.68 & 5.07 & 24.93 \\
\hline
\end{tabular}

*,** Significant in $5 \%$ and $1 \%$, respectively, ns: Non significant

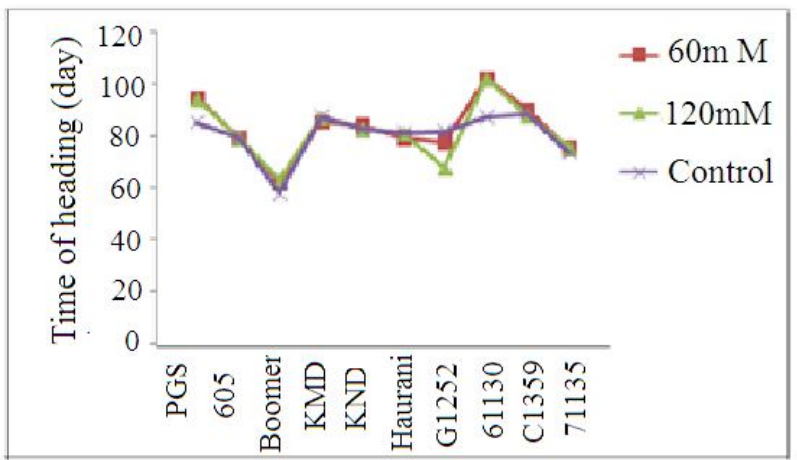

Figure 2. Interaction of salinity and cultivars for time of heading in durum wheat
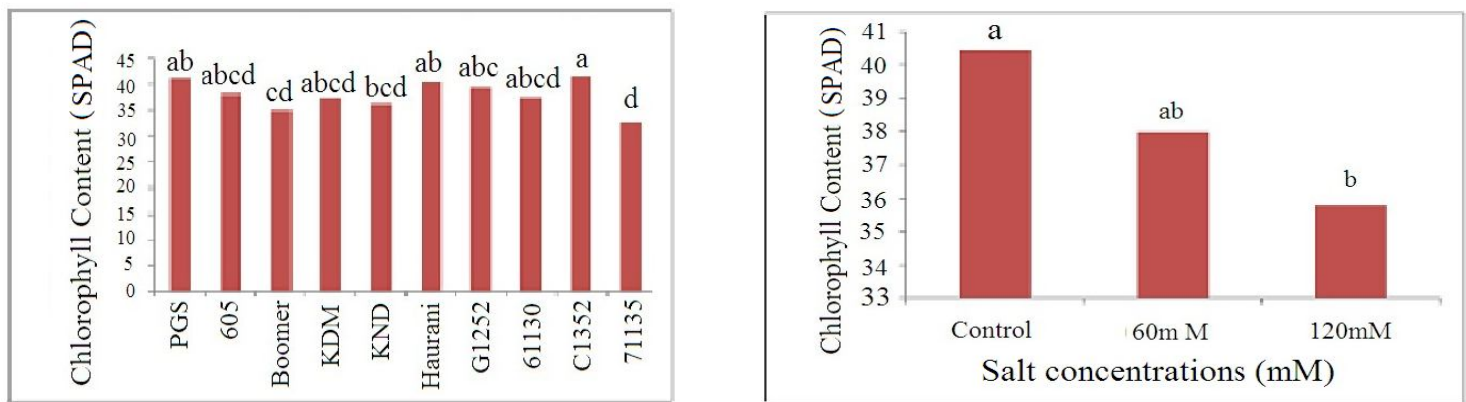

Figure 3. Comparison of means for the chlorophyll content of flag leaf $(\mathrm{P}<5 \%)$ under different levels of salinity (right) and durum wheat cultivars (left) 
Table 2-Comparison of means for the salt $\times$ cultivar for flag leaf chlorophyll fluorescence

\begin{tabular}{cccc}
\hline \multicolumn{3}{c}{ Salinity levels } \\
\hline cultivars & control & $60 \mathrm{mM}$ & $120 \mathrm{mM}$ \\
Boomer & $0.726 \mathrm{ab}$ & $0.737 \mathrm{a}$ & $0.756 \mathrm{a}$ \\
G1252 & $0.712 \mathrm{~b}$ & $0.695 \mathrm{~b}$ & $0.674 \mathrm{c}$ \\
$\mathbf{6 0 5}$ & $0.740 \mathrm{ab}$ & $0.741 \mathrm{a}$ & $0.741 \mathrm{a}$ \\
KND & $0.739 \mathrm{ab}$ & $0.715 \mathrm{a}$ & $0.733 \mathrm{ab}$ \\
KDM & $0.756 \mathrm{a}$ & $0.733 \mathrm{a}$ & $0.751 \mathrm{a}$ \\
$\mathbf{7 1 1 3 5}$ & $0.712 \mathrm{~b}$ & $0.730 \mathrm{a}$ & $0.705 \mathrm{bc}$ \\
$\mathbf{6 1 1 3 0}$ & $0.724 \mathrm{ab}$ & $0.715 \mathrm{ab}$ & $0.706 \mathrm{bc}$ \\
Haurani & $0.707 \mathrm{~b}$ & $0.731 \mathrm{a}$ & $0.713 \mathrm{~b}$ \\
C1352 & $0.743 \mathrm{ab}$ & $0.683 \mathrm{~b}$ & $0.749 \mathrm{a}$ \\
PGS & $0.720 \mathrm{ab}$ & $0.725 \mathrm{a}$ & $0.632 \mathrm{~d}$ \\
\hline
\end{tabular}

In each column means with same letters are not different statistically, using LSD test at $1 \%$ level.

\section{Conclusion}

In this study, time of stem elongation and time to maturity in durum wheat cultivars was not affected from salinity, but time to heading was different among cultivars and salinity levels. So, with considering to simplicity of measuring this criterion, it can be used as phenological trait for screening of durum wheat cultivars against salinity stress.

\section{References}

Acevedo E, Silva P, Silva H (2002). Wheat Growth and Physiology. pp.39-70,In: Bread wheat improvement and production. Curtis BC, Rajaram S and Gómez Macpherson H (eds). FAO, Roma, Italy.

Ashraf M, Foolad MR (2005). Pre-sowing seed treatment-a shotgun approach to improve germination, plant growth and crop yield under saline and non-saline conditions. Adv. Agron. 88: 223-271.

Ashrafuzzaman M, Khan MAH,Shohidullah SM, Rahman MS (2000). Effect of salinity on the chlorophyll content, yield and yield components of QPM cv. Nutricta. Pakistan J. Biol. Sci. 3(1): 43-46.

Baker NR, Rosenqvist E (2004). Application of chlorophyll fluorescence can improve crop production strategies: An examination of future possibilities. J. Exp. Bot. 55 (403): 1607-1621.

Dell JR, Van cooten O, Prange RK, Murr DP (1999). Applications of chlorophyll fluorescence techniques in post harvest physiology. Hort. Rev. 23: 69-107.

Dingkuhn M, De Datta SK, Pamplona R, Javellana C, Schnier HF (1992). Effect of late- season N fertilization on photosynthesis and yield of transplanted and direct- seeded tropical flooded rice.II.A canopy stratification study. Field Crops Res., 28(3): 235-249.

Drazkiewics M (1994). Chlorophyllase: Occurance functions, mechanisms of action, effects of external and internal factors. Photosynthesis. 30: 321-331.

Frank AB, Bauer A, Blak AL (1987). Effects of temperature and water stress on apex development in wheat. Crop Sci. 27: 113-116.

Golabadi M, Arzani A, EbrahimSeyedTabatabaie B, Mohamadi A (2008). Identification of SSR markers linked with genes controlling phonological characteristics of durum wheat under moisture stress and non stress. In: Proceedings of the Tenth Congress of Genetics, May 21-23, Tehran, Iran.

Grieve CM, Francois LE, Maas EV (1994). Salinity affects the timing of phasic development in spring wheat. Crop Sci. 34(6): 1544-1549.

Iqbal N, Ashraf M, FarrukhJaved, Vicente Martinez, Kafeel Ahmad (2006). Nitrate reduction and nutrient accumulation in wheat (Triticum aestivumL.) grown in soil salinization with four different salts. J Plant Nutr. 29(3): 409-421.

Kafi M (2001). Apex development of three wheat cultivars in the presence of salinity. J. Agric. Sci. Technol. 3: 1-8. 
Kao WY, Tsai TT, Shih CN (2003). Photosynthetic gas exchange and chlorophyll a fluorescence of three wild soybean species in response to $\mathrm{NaCl}$ treatments. Photosynthetica, 41: 415-419.

Maas E, Grieve C (1986). Salt tolerance of plants. Appl. Agric Res. 1(1): 12-26.

Mass EV, Poss JA (1989). Salt sensitivity of cowpea at various growth stages. Irri. Sci. 10:313-320.

McMaster GS, Morgan JA, Wilhelm WW (1992a). Simulating winter wheat spike development and growth. Agric. For. Meteorol. 60: 193-220.

Misra AN, Srivastava A, Strasser RJ (2001).Utilization of fast chlorophyll fluorescence technique in assessing the salt/ion sensitivity of mung bean and Brassica seedlings. J. Plant Physiol. 158:1173-1181.

Moussa RH (2006). Influence of Exogenous Application of Silicon on physiological Response of Saltstressed Maize (Zea mays L.). Int. J. Agri. Biol., 8: 293-297.

Munns R (1993). Physiological processes limiting plant growth in saline soil: some dogmas and hypotheses. Plant, Cell Environ. 16: 15-24.

Neumann PM (1995). Inhibition of root growth by salinity stress: toxicity or adaptive biophysical response? In: Baluska, F., Ciamporova, M., Gasparikova, O., Barlow, P.W., (Eds.), Structure and Function of Roots: Developments in Plant and Soil Sciences. Kluwer Academic Pubishers, Netherlands, pp 299-304.

Oosterhuis DM, Cartwright PM (1983). Spike Differentiation and Floret Survival in Semi-dwarf Spring Wheat as Affected by Water Stress and Photoperiod. Crop Sci., 23(4): 711-717.

Pessarakli M (Ed.). (1999). Handbook of Plant and Crop Stress, 2nd Edition, Revised and Expanded, Marcel Dekker, Inc., New York, 1254 p.

Reddy MP, Vora AB (1986). Salinity induced changes in pigment composition and chlorophyllase activity of wheat. Indian. J. Plant. 29(4): 331-334.

Termaat A, Munns R (1986). Use of concentrated macronutrient solutions to separate

osmotic from NaCl-specific effects on plant growth. Aust. J. Plant Physiol. 13: 509-522.

Zair I, Chlyah A, Sabounji K, Tittahsen M, Chlyah H (2003). Salt tolerance improvement in some wheat cultivars after application of in vitro selection pressure. Plant Cell Tissue Organ Cult., 73: 237244.

Zhao GQ, Ma BL, Ren CZ (2007). Growth, gas exchange, chlorophyll fluorescence and ion content of naked oat in response to salinity. Crop Sci., 47(1): 123-131. 